\title{
PERAN MEDIA SOSIAL INSTAGRAM DALAM MENINGKATKAN MINAT BERWIRAUSAHA PESERTA DIDIK DI SMK PLUS PELITA NUSANTARA
}

\author{
Nada Cania ${ }^{1}$, Rosalina Dewi Heryani ${ }^{2(*)}$ \\ Universitas Indraprasta PGRI Jakarta, Indonesia \\ nadacania@gmail.com¹, rosalina.dewi7@gmail.com²
}

\begin{abstract}
Received: 16 September 2020 Penelitian bertujuan untuk mengetahui peran media sosial dalam Revised: 17 September 2020 meningkatkan minat berwirausaha peserta didik kelas XI jurusan Accepted: 21 September 2020 perbankan di SMK Plus Pelita Nusantara. Menggunakan metode penelitian kualitatif deskriptif dengan melakukan wawancara kepada 10 informan yang memiliki akun instagram dengan followers lebih dari 700 dengan teknik purposive sampling, dokumentasi dan trianggulasi. Hasil wawancara menunjukkan bahwa instagram berperan dalam meningkatkan minat berwirausaha peserta didik yaitu sebagai media promosi dan wadah untuk berjualan secara online sehingga tidak perlu bertemu langsung dengan konsumen. Dengan begitu peserta didik tidak perlu mengeluarkan banyak biaya untuk membuat brosur, dan tidak perlu menyewa tempat berjualan yang mahal. Namun minat atau rasa ketertarikan peserta didik terhadap berwirausaha masih perlu ditingkatkan dan dilatih lagi. Hal tersebut disebabkan oleh peserta didik yang merasa kurang memiliki rasa percaya diri, kurang kreatif, kurang modal, dan belum berani mengambil resiko kerugian dalam sebuah usaha. Cara mengatasinya dengan memaksimalkan penggunaan akun instagram mereka. Apabila peserta didik memiliki banyak followers maka besar kemungkinan produk yang dijual berpotensi memiliki pembeli yang banyak. Sehingga media instagram dapat meningkatkan minat berwirausaha peserta didik khususnya pada kelas XI Perbankan di SMK Plus Pelita Nusantara.
\end{abstract}

Keywords: Media Sosial; Instagram ; Minat Berwirausaha

(*) Corresponding Author: Heryani, rosalina.dewi7@gmail.com, 08568688130

How to Cite: Cania, N. \& Heryani, R. D. (2020). Peran Media Sosial Instagram Dalam Meningkatkan Minat Berwirausaha Peserta Didik Di SMK Plus Pelita Nusantara. Research and Development Journal of Education, 1(1), 91-101.

\section{INTRODUCTION}

Dunia saat ini telah memasuki revolusi industri 4.0, dimana semua lini kehidupan berbasis online. Perkembangan dunia teknologi saat ini mengharuskan internet sebagai salah satu alat komunikasi, pertukaran data, dan media pencari informasi yang banyak diminati oleh setiap kalangan terutama generasi milenial. Dampaknya terjadi perubahan yang signifikan, hampir semua transaksi menggunakan sistem online. Sehingga internet menjadi kebutuhan sehari-hari. Namun demikian harus kita akui dan waspadai bahwa internet seperti pisau bermata dua, ada sisi positif dan sisi negatifnya yang dapat memberikan dampak bagi para penggunanya.

Sebagai pengguna internet kita harus cerdas dan pandai dalam memanfaatkan serta mencari peluang. Salah satu cara memanfaatkan internet yaitu dengan menciptakan peluang bisnis yang ada dengan menggunakan media sosial. Dimana dengan menggunakan media sosial saat ini dapat membuka lahan bisnis yang berpotensi besar 
bagi para calon wirausaha dan wirausaha yang sudah menjalankan bisnisnya sehingga mampu meningkatkan nilai penjualan dan kinerja usahanya, serta memberikan banyak keuntungan.

Seperti diungkapkan oleh Zarella (dalam Aditya, 2015:3) bahwa media sosial merupakan suatu situs yang dijadikan sebagai tempat untuk berkomunikasi dengan teman-teman yang ada di dunia nyata dan maya. Sehingga berperan sebagai media berbasis internet untuk saling berbagi ide, menciptakan kreasi, dan membangun komunitas melalui konten berupa pesan, gambar, dan video.

Menurut survey, pengguna internet di Indonesia sangat menggemari media sosial dilihat dari data hasil riset We are Sosial Hootsuite melalui databoks yang dirilis bulan Februari 2020, penggunanya di Indonesia hingga 160 juta atau sebesar 59\% dari total penduduk Indonesia. Rata-rata waktu yang digunakan untuk bermedia sosial adalah 3 jam 26 menit per hari (Databoks, 2020). Untuk aplikasi media sosial yang paling banyak diguakan dapat dilihat dari data hasil riset We are Social Hootsuite melalui databoks yang dirilis bulan Februari 2020 yaitu :

Tabel 1.

Media Sosial Paling Banyak di Gunakan di Indonesia Tahun 2020

\begin{tabular}{llc}
\hline No. & Media Sosial & Persentase Penggunaan Media Sosial \\
\hline 1 & Youtube & 88\% Pengguna \\
2 & Whatsapp & $84 \%$ Pengguna \\
3 & Facebook & $82 \%$ Pengguna \\
4 & Instagram & $79 \%$ Pengguna \\
5 & Twitter & $56 \%$ Pengguna \\
\hline \multicolumn{2}{c}{ Sumber: Databoks.katadata.co.id, 2020 }
\end{tabular}

Youtube menduduki urutan pertama penggunaan media sosial sebanyak $88 \%$, diikuti oleh WhatsApp 84\%, Facebook 82\%, Instagram 79\%, dan Twitter 56\% pengguna. Jika dilihat dari umur dan jenis kelamin, bahwa pengguna media sosial yang paling banyak digunakan oleh usia dari 16-64 tahun (Databoks, 2020). Walaupun instagram hanya ada diposisi ke empat, namun instagram merupakan salah satu aplikasi yang paling disukai untuk memasarkan beraneka produk dikarenakan instagram berfokus pada penggunaan gambar dan video yang memiliki banyak fitur. Dengan menggunakan instagram tentunya produk yang diiklankan akan memiliki nilai lebih ketika diperlihatkan dalam akun instagram yang memiliki banyak followers. Para influencer memanfaatkan akun instagram mereka untuk memasarkan produk sendiri maupun produk orang lain. Sehingga semakin banyak followers yang dimiliki, maka semakin banyak peluang para konsumen untuk membelinya. Selain itu, instagram juga memiliki label foto yang dapat digunakan sebagai kata kunci yang berhubungan dengan gambar tersebut. Semakin banyak hastag yang dimasukan juga akan semakin mudah melakukan pencarian mengenai foto tersebut. Like atau tombol suka juga dapat memberikan pesan bahwa video atau foto yang diunggah dan disukai oleh banyak orang artinya foto atau video tersebut populer dan menarik. Sehingga seiring dengan berjalannya waktu seorang wirausaha menyadari bahwa instagram dapat dimanfaatkan sebagai media untuk memasarkan produknya dan memperoleh peluang bisnis dari media sosial tersebut.

Menurut Wirasamita (dalam Suryana dan Bayu, 2010:25) menyebutkan kewirausahaan dan wirausaha adalah segala kegiatan produksi yang dapat memanfaatkan sumber daya, teknologi, dan modal sehingga dapat menciptakan lapangan pekerjaan, penghasilan, dan produk yang memang dibutuhkan masyarakat. Dalam berwirausaha, seseorang harus memiliki minat berwirausaha terlebih dahulu karena minat dapat membuat seseorang melakukan sesuatu dengan maksimal. Dengan adanya minat seseorang akan merencanakan dengan baik usahanya dimulai dari awal pembukaan usaha 
sampai masa yang akan datang. Saat ingin melakukan usaha seseorang harus merubah pola pikir dalam menjalankan usahanya yaitu dengan cara memanfaatkan peluang serta menggunakan teknologi dalam berwirausaha.

Berdasarkan observasi awal terhadap peserta didik khususnya kelas XI jurusan perbankan di SMK Plus Pelita Nusantara, mereka adalah pengguna media sosial dan memiliki akun instagram. Dari hasil observasi tersebut peneliti menemukan masih rendahnya minat berwirausaha pada peserta didik. Hal ini disebabkan oleh beberapa faktor, diantaranya kurangnya percaya diri, kurangnya modal, kurang kreatif, dan rendahnya pengetahuan tentang kewirausahaan.

SMK Plus Pelita Nusantara adalah salah satu sekolah yang membekali para peserta didiknya untuk menjadi wirausaha. Misi SMK Plus Pelita Nusantara yaitu menumbuhkan jiwa entrepreneurship kepada peserta didik, khususnya peserta didik kelas XI jurusan perbankan yang telah mendapatkan mata pelajaran kewirausahaan. Penelitian serupa sudah pernah dilakukan. Namun terdapat beberapa perbedaan antara penelitian ini dengan penelitian sebelumnya, antara lain subjek dan objek penelitiannya (Adinda dan Pangestuti, 2019), jenis penelitian dan variabelnya (Rahayu dan Laela, 2018), dan teknik analisis datanya (Nordiana, 2014).

\section{LITERATURE REVIEW}

\section{Media Sosial}

\section{Definisi Media Sosial}

Menurut Turban (dalam Fikrian, 2018:28), "Media sosial adalah media yang melibatkan penggunanya dalam menghasilkan konten berupa pesan, audio, gambar, dan video melalui perantara piranti Web 2.0". sedangkan menurut Zarella (dalam Aditya, 2015:3), "Media sosial merupakan tempat orang berkomunikasi dengan teman di dunia nyata maupun maya".

\section{Klasifikasi Media Sosial}

Menurut Kaplan dan Haenlein (dalam Nurkarima, 2018:13-14), media sosial diklasifikasikan menjadi enam jenis, yaitu:

a. Proyek kolaborasi website yaitu pengguna diperbolehkan untuk mengubah, menambah, ataupun membuang konten yang ada di website tersebut. Contohnya wikipedia.

b. Blog dan microblog yaitu pengguna diberikan kebebasan untuk mengungkapkan sesuatu diblog tersebut, misalnya perasaan, pengalaman, pernyataan, maupun saran. Contohnya blogspot, wordpress.

c. Konten yaitu pengguna dapat membagikan konten-konten multimedia seperti gambar, foto, video dan lainnya. Contohnya instagram dan youtube.

d. Situs jejaring sosial yaitu aplikasi yang memungkinkan penggunanya terhubung dengan menggunakan profil pribadi. Contohnya facebook, instagram.

e. Dunia game virtual yaitu lingkungan tiga dimensi, dimana pengguna dapat berinteraksi dengan pengguna lain menggunakan avatar pribadi. Contohnya game online PUBG, ML.

f. Dunia sosial virtual yaitu aplikasi berwujud dunia virtual yang memungkinkan penggunanya hidup di dunia virtual dan berinteraksi dengan yang lain. Contohnya second life. 


\section{Fungsi Media Sosial}

Media sosial memiliki fungsi yang berbeda-beda bagi para penggunanya. Secara umum, media sosial berfungsi untuk memperluas interaksi sosial bagi penggunanya dengan memanfaatkan teknologi internet. Sehingga pengguna media sosial dapat berinteraksi dengan orang lain dari seluruh penjuru dunia.

\section{Instagram}

Instagram berasal dari kata instan dan telegram. Kata instan yaitu kamera polaroid, sedangkan kata telegram yaitu mengirimkan informasi kepada orang lain dengan cepat. Menurut Atmoko (dalam Adinda dan Pangestuti, 2019:177), "Instagram merupakan aplikasi smartphone yang mempunyai fungsi sama dengan twitter namun perbedaannya pada pengambilan foto sebagai tempat untuk berbagi informasi terhadap penggunanya".

Dapat disimpulkan bahwa instagram merupakan aplikasi untuk membagikan video dan foto dengan menggunakan filter digital sehingga tampilan foto lebih terlihat bagus dan menarik. Dengan tampilan yang menarik maka foto, video, atau produk yang ditawarkan dapat menarik minat calon pembeli, sehingga media instagram sangat relevan untuk dijadikan aplikasi bisnis secara online.

Menurut Sidiq (2017:23), instagram memiliki lima menu utama, antara lain :

a. Homepage adalah halaman utama yang menampilkan foto-foto terbaru dari sesama pengguna yang telah diikuti.

b. Comments adalah menu yang dapat digunakan pengguna untuk meninggalkan komentar atas foto, video yang diunggah oleh pemilik akun.

c. Explore adalah tampilan dari foto-foto populer yang paling banyak disukai para pengguna instagram.

d. Profil adalah tampilan detail tentang informasi pengguna, maupun sesama pengguna lainnya. Menampilkan seluruh foto yang telah di upload, jumlah follower dan following.

e. News Feed adalah fitur yang menampilkan pemberitahuan terhadap aktivitas yang telah dilakukan oleh pengguna instagram.

Terdapat beberapa aktivitas yang ada di aplikasi Instagram. Menurut Sidiq (2017:25) antara lain :

a. Follow adalah pengikut dari pengguna instagram agar mengikuti atau berteman dengan pengguna lain yang menggunakan instagram.

b. Like adalah suatu menu dimana pengguna dapat menyukai postingan pada instagram dengan cara menekan tombol like dibagian bawah caption sebelah komentar, cara kedua dengan double tap pada postingan yang disukai.

c. Komentar adalah aktivitas memberikan pendapat, pujian, atau kritikan.

d. Mentions adalah sebuah fitur untuk menambah pengguna lain dengan cara menambah tanda arroba atau at (@) dan memasukkan instagram pengguna tersebut.

\section{Minat Berwirausaha}

\section{Kewirausahaan dan Wirausaha}

Menurut Wirasamita (dalam Suryana dan Bayu, 2010:25), "Kewirausahaan dan Wirausaha adalah faktor produksi yang menggerakkan dan memanfaatkan sumber daya lainnya seperti sumber daya modal, alam, dan teknologi sehingga menciptakan kekayaan dan kemakmuran melalui pembukaan lapangan kerja, penghasilan dan produk yang diperlukan masyarakat". Menurut Prawirokusumo (dalam Anwar, 2014:19), "Wirausaha adalah mereka yang melakukan upaya kreatif dan inovatif 
dengan mengembangkan ide untuk menemukan peluang dan perbaikan hidup". Wirausaha wajib memiliki sikap dan perilaku yang baik dalam berwirausaha, agar usaha yang dijalankan dapat berjalan sesuai dengan tujuan yang diinginkan serta konsisten. Menurut Kasmir (2011), sikap dan perilaku yang harus dimiliki oleh seorang wirausaha antara lain jujur dalam bertindak dan bersikap. Rajin, tepat waktu, dan tidak pemalas. Lemah lembut dan ramah. Sopan santun dan hormat. Serta serius dan memiliki tanggung jawab.

\section{Minat Berwirausaha}

Menurut Yanto (dalam Wulandari, 2013:6), "Minat wirausaha adalah kemampuan untuk memberanikan diri dalam memenuhi kebutuhan hidup, memajukan usaha atau menciptakan usaha baru dengan kekuatan yang ada pada diri sendiri. Minat berwirausaha dapat juga diartikan sebagai ketertarikan seseorang terhadap dunia wirausaha yang timbul berdasarkan kemauan dari dalam diri sendiri tanpa ada paksaan dari pihak lain, disertai ketertarikan untuk mempelajari kewirausahaan lebih mendalam. Sehingga timbul keinginan untuk membuka usaha sendiri.

\section{METHODS}

\section{Jenis Penelitian}

Jenis penelitian kualitatif deskriptif, dimana peneliti memperoleh data yang bersifat apa adanya, dan lebih menekankan makna daripada hasil.

\section{Situasi Sosial}

Penelitian kualitatif tidak mengenal istilah populasi dan sampel, namun situasi sosial. Situasi sosial itu sendiri terbagi menjadi tiga unsur yaitu tempat (place), pelaku (actors), dan aktivitas (activity). Tempat yang dimaksud adalah SMK Plus Pelita Nusantara yang berlokasi di Cibinong, Jawa Barat. Pelakunya yaitu informan atau orang yang akan menjadi sumber data oleh peneliti. Dan aktivitas yaitu dengan mengamati dan mewawancarai para informan yang berjumlah 10 peserta didik.

\section{Teknik Pengumpulan Data}

a. Observasi

Observasi dilakukan oleh peneliti dengan melakukan pengamatan di SMK Plus Pelita Nusantara dengan menggunakan bantuan lembar observasi dengan memberi tanda ceklist.

b. Wawancara

Peneliti melakukan wawancara secara terstruktur dengan menggunakan pedoman wawancara kepada 10 peserta didik dengan jumlah pertanyaan sebanyak 18 butir.

c. Dokumentasi

Dokumentasi berfungsi untuk memperkuat data yang diperlukan dalam penelitian. Dokumentasi yang dimaksud disini adalah buku, jurnal, hasil wawancara, foto yang ada kaitannya dengan objek penelitian.

d. Trianggulasi

Penelitian ini menggunakan trianggulasi teknik yaitu menggabungkan tiga teknik pengumpulan data yaitu observasi, wawacara, dan dokumentasi.

\section{Teknik Analisis Data}

Teknik analisis data digunakan untuk menjawab pertanyaan penelitian yaitu dengan menggunakan : 
a. Reduksi data, yaitu mengumpulkan, memilih, memfokuskan pada hal yang penting, mencari tema dan polanya, serta membuang yang tidak dibutuhkan.

b. Penyajian data, yaitu data disajikan dalam bentuk uraian atau deskripsi yang jelas dan lugas,serta menggambarkan situasi yang sebenarnya.

c. Penarikan simpulan, yaitu simpulan diambil untuk dapat menjawab pertanyaan penelitian dan sebagai pedoman untuk menyusun laporan penelitian.

\section{RESULTS \& DISCUSSION}

Penelitian ini dilakukan di SMK Plus Pelita Nusantara yang beralamat Lingkungan 03, Jalan Golf RT. 08 RW. 06, Ciriung, Cibinong, Bogor Jawa Barat. Pelaksanaan penelitian dilakukan dengan teknik pengumpulan data melalui observasi, wawancara, dokumentasi, dan trianggulasi dengan beberapa narasumber yang terkait langsung dengan masalah minat berwirausaha peserta didik kelas XI Perbankan. Terdapat 10 narasumber yang berhasil diwawancarai oleh peneliti yaitu peserta didik yang memiliki akun Instagram dengan followers diatas 700.

berikut :

Adapun data informan yang berhasil diwawancarai oleh peneliti sebagai

Tabel 2.

Daftar Informan

\begin{tabular}{cllcc}
\hline No. & Informan (Akun IG) & Nama Peserta Didik & Kelas & Jumlah Followers \\
\hline 1 & nadivazla & Nadiva Zalza Aulia & PKM-2 & 1.178 \\
2 & syalwaafm & Syalwa Fitria Maharani & PKM-2 & 874 \\
3 & nissa.as & Nissa Azhzara Septiani & PKM-2 & 749 \\
4 & alifa.sl & Alifa Suli Lutfia & PKM-2 & 1.071 \\
5 & luthfiaharfna & Luthfiah Arfina & PKM-2 & 1.323 \\
6 & dheafbrynti_ & Dhea Febriyanti & PKM-2 & 785 \\
7 & angelicaaaa.g_ & Angelica Genesaret & PKM-2 & 806 \\
8 & anandalifya & Ananda Alifya & PKM-2 & 1.210 \\
9 & mldanvsh & Maulida Navisah & PKM-3 & 1.248 \\
10 & ashillamr & Asilah Malika Rizki & PKM-3 & 1.111 \\
\hline
\end{tabular}

Sumber: Peneliti (2020)

Setelah semua informan di wawancarai maka semua data hasil penelitian diuraikan dengan fokus pertanyaan sebagai berikut :

\section{Minat Berwirausaha}

Apakah minat yang rendah dapat menyebabkan peserta didik malas berwirausaha?

Berdasarkan jawaban informan dapat disimpulkan bahwa dalam memulai suatu usaha atau berwirausaha yang dibutuhkan pertama kali yaitu adanya minat karena minat tidak dapat dipaksakan dan muncul dengan sendirinya. Minat ini yang akan mendorong peserta didik untuk mengerjakan yang menjadi minatnya. Apabila tidak ada minat maka yang akan terjadi usaha yang akan dilakukan tidak akan berjalan dan bertahan dalam jangka waktu yang lama.

\section{Minat Berwirausaha Peserta Didik Kelas XI di SMK Plus Pelita Nusantara}

Apakah kalian berminat berwirausaha?

Berdasarkan jawaban informan, sebagian besar peserta didik memiliki minat berwirausaha yang tinggi sehingga mereka dapat memanfaatkan peluang dan 
kesempatan yang ada seperti berjualan di dalam kelas, berjualan dilingkungan sekolah, serta berjualan melalui akun instagram yang mereka miliki.

\section{Penyebab Kurangnya Minat Berwirausaha}

Apa saja yang menjadi penyebab kurangnya minat peserta didik dalam berwirausaha?

Dapat disimpulkan bahwa penyebab kurangnya minat peserta didik dalam berwirausaha yaitu kurangnya rasa percaya diri, kurangnya modal, kurang kreatif, dan rendahnya pengetahuan tentang kewirausahaan.

\section{Minat Berwirausaha Informan}

Peneliti memberikan pengukuran minat berwirausaha berupa persentase kepada informan. Dari hasil wawancara ditemukan 9 dari 10 informan memiliki minat berwirausaha. Sehingga tidak sulit bagi peserta didik yang memiliki minat berwirausaha untuk memulai usaha dengan baik.

\section{Alasan Informan Berminat atau Tidak Berminat dalam Berwirausaha}

Setiap tindakan yang dilakukan pasti memiliki alasan, begitu pula dalam berwirausaha. Informan menyadari bahwa berwirausaha memberikan dampak positif bagi dirinya dan orang lain. Karena dengan berwirausaha informan dapat menghasilkan uang saku tambahan dan akan mengurangi jumlah pengangguran yang ada, sehingga dapat meningkatkan perekonomian.

\section{Keberanian Informan untuk Berwirausaha}

Setelah adanya minat untuk berwirausaha dalam diri sendiri kemudian wirausaha wajib memiliki keberanian dalam berwirausaha. Menurut peneliti keberanian adalah sikap utama yang wajib dimiliki oleh seseorang yang ingin berwirausaha. Dengan adanya keberanian maka seseorang akan dapat melangkah dan menghadapi kesulitan yang mungkin terjadi. Namun masih disayangkan hanya ada 4 informan yang telah memiliki keberanian untuk berwirausaha, sedangkan sisanya 6 informan belum memiliki keberanian.

\section{Alasan Informan Berani atau Tidak Berani untuk Berwirausaha}

Berdasarkan informasi yang diterima dari 4 informan yang sudah berani untuk berwirausaha, mereka mengemukakan pendapat bahwa mereka berani mencoba berwirausaha karena mereka telah memperaktikkannya dengan berjualan hijab, tas, makanan ringan secara online sehingga sudah terbiasa untuk berwirausaha. Sedangkan 6 informan yang belum berani beralasan bahwa mereka kurang percaya diri dan takut akan produk yang dijual tidak laku dibeli oleh konsumen, kurangnya koneksi atau jaringan untuk memasarkan produk, sehingga khawatir usahanya tidak akan berjalan dan berkelanjutan.

\section{Jenis Usaha yang Ingin dilakukan Informan}

Saat ini banyak masyarakat yang sulit untuk mendapatkan pekerjaan. Membuka usaha sendiri dapat membuka peluang untuk menghasilkan uang. Menurut peneliti usaha merupakan kegiatan yang menghasilkan barang atau jasa lalu menjualnya kepada konsumen sehingga mendapatkan keuntungan. Banyak sekali potensi pasar yang dapat dimanfaatkan seperti membuka usaha kuliner dimana saat ini usaha ini sedang naik daun dan tidak pernah sepi peminat, pakaian wanita mulai dari jilbab, gamis, celana yang seakan modelnya terus berganti mengikuti trend, 
kosmetik dan kecantikan usaha ini juga sangat diminati mengingat kosmetik merupakan kebutuhan dasar setiap wanita.

\section{Media Sosial Instagram}

Media sosial adalah media online yang dapat memudahkan penggunanya untuk mendapatkan informasi yang dibutuhkan. Selain untuk mendapatkan informasi, media sosial juga berfungsi sebagai media untuk mempromosikan dan berjualan seperti Instagram. Peneliti juga menanyakan perihal apakah Instagram berperan dalam meningkatkan minat berwirausaha dan semua informan berpendapat bahwa media sosial instagram sangat berperan penting dalam meningkatkan minat berwirausaha karena dewasa ini banyak para pengguna instagram yang memanfaatkan akun instagram yang mereka miliki untuk menjual produk yang mereka hasilkan.

\section{Peran Media Sosial Instagram}

Terkait dengan pertanyaan sebelumnya mengenai media sosial instagram sangat berperan dalam meningkatkan minat berwirausaha, maka peneliti tergelitik untuk mengetahui alasannya antara lain media sosial instagram berperan sebagai media promosi secara online dengan begitu informan tidak perlu mengeluarkan banyak biaya untuk membuat brosur, untuk menyewa tempat yang mahal. Apabila informan memiliki akun instagram yang memiliki banyak followers maka dengan banyak followers yang dimiliki kemungkinan besar produk yang dijual akan semakin banyak yang membeli seperti influencer. Influencer merupakan seseorang yang memiliki followers yang banyak di instagram. Sehingga bisa mempromosikan produknya sendiri maupun produk orang lain.

\section{Pengaruh Tingkat Pendidikan Seseorang untuk Berwirausaha}

Menuntut ilmu atau belajar adalah suatu keharusan yang perlu dilakukan agar tidak terjebak pada keterpurukan karena kebodohan. Cara untuk menuntut ilmu sangat banyak, ada yang belajar langsung dari pengalaman hidup, ada yang belajar dibangku sekolah, dan ada juga yang belajar dari kesalahan diri sendiri dan orang lain.

Begitu juga pengusaha, ada pengusaha sukses yang tidak memiliki pendidikan tinggi namun banyak juga pengusaha sukses yang mengenyam pendidikan. Terkait dengan pertanyaan wawancara "Apakah tingkat pendidikan seseorang dapat mempengaruhi orang tersebut untuk berwirausaha?". Berdasakan hasil wawancara 6 informan berpendapat bahwa tingkat pendidikan seseorang bisa memengaruhi orang tersebut untuk berwirausaha, dan 4 informan lainnya berpendapat bahwa tingkat pendidikan seseorang tidak bisa memengaruhi orang tersebut untuk berwirausaha.

\section{Alasan Tingkat Pendidikan dapat Memengaruhi Seseorang untuk Berwirausaha}

Informan 6 dan 7 berpendapat bahwa tingkat pendidikan seseorang tidak dapat memengaruhi orang tersebut untuk berwirausaha karena semua tergantung dari minat, tekad, dan keberanian masing-masing. Ada orang yang memiliki pendidikan tinggi namun dia tidak memiliki minat untuk berwirausaha maka usahanya tidak akan berjalan dengan baik, sebaliknya apabila dia berpendidikan rendah namun memiliki minat berwirausaha maka usahanya akan maju. Sebaliknya informan 8 berpendapat bahwa apabila seseorang memiliki pendidikan yang tinggi maka ide yang dimiliki akan semakin lebih banyak sehingga pengetahuan dan wawasan dalam berwirausaha semakin luas sehingga berpotensi usahanya semakin maju. 
Dapat disimpulkan bahwa pendidikan yang tinggi sangat penting karena akan memberikan banyak jaringan pertemanan dan wawasan yang luas mengenai berwirausaha. Namun setiap orang mempunyai karakter yang berbeda dengan kondisi yang dihadapi pun berbeda. Sehingga keputusan untuk berpendidikan tinggi atau tidak adalah pilihan masing-masing individu. Tetapi tetap untuk menjadi wirausaha yang sukses diperlukan jiwa pembelajar yang tiada pernah henti serta diperlukannya minat, tekad, dan keberanian yang kuat.

\section{Pengaruh Potensi dan Prestasi yang Tinggi Seseorang untuk Berwirausaha}

Menurut peneliti potensi dan prestasi tinggi merupakan sesuatu yang penting untuk seorang wirausaha dalam menjalankan usahanya. Hal ini karena seorang wirausaha tidak mengenal pantang menyerah didalam mencapai tujuan yang telah ditetapkan sendiri. Terkait dengan pertanyaan wawancara hanya 1 informan yang berpendapat bahwa potensi dan prestasi yang tinggi tidak dapat memengaruhi seseorang untuk memulai berwirausaha. Sedangkan informan 2 sampai 10 berpendapat bahwa potensi dan prestasi dapat memengaruhi seseorang untuk memulai berwirausaha.

\section{Alasan Potensi dan Prestasi yang Tinggi dapat Memengaruhi Seseorang untuk} Berwirausaha

Dari ke 9 informan mereka berpendapat bahwa potensi dan prestasi yang tinggi dapat memengaruhi seseorang untuk memulai berwirausaha karena apabila seseorang sudah mengetahui potensi yang ada didalam dirinya sendiri maka orang tersebut akan dapat memulai berwirausaha sehingga perlahan prestasi akan muncul sebagai apresiasi terhadap kemampuan dan keahlian yang dimiliki sehingga secara langsung dapat berkreativitas didalam usahanya sendiri.

\section{Dukungan Keluarga untuk Terjun ke Bidang Kewirausahaan}

Menurut peneliti dukungan merupakan dorongan yang diberikan kepada seseorang agar orang tersebut semangat dalam melakukan sesuatu hal. Terkait dengan pertanyaan wawancara "Seberapa besar dukungan keluarga untuk anda terjun ke bidang kewirausahaan?". Dapat disimpulkan semua informan berpendapat bahwa dukungan keluarga sangat besar untuk bisa terjun ke bidang kewirausahaan

16. Alasan Dukungan Keluarga Sangat Diperlukan untuk Terjun ke Bidang Kewirausahaan

Dukungan keluarga pada dasarnya adalah sikap atau tindakan yang selalu mendorong dan akan selalu memberikan pertolongan, bantuan, dan semangat kepada informan sehingga dapat membuat lebih percaya diri untuk berwirausaha. Dukungan ini sangat diperlukan karena dengan dukungan, informan lebih bersemangat dan termotivasi untuk berwirausaha pada akhirnya hasil yang didapat bisa berguna dan membantu perekonomian keluarga.

\section{Pengaruh Lingkungan dan Pergaulan untuk Berwirausaha}

Menurut peneliti dorongan untuk menumbuhkan jiwa wirausaha dapat berawal dari lingkungan pergaulan teman, keluarga, sekolah karena dapat berdiskusi tentang ide berwirausaha, masalah yang dihadapi saat berjualan dan cara-cara mengatasi hal tersebut. Sehingga semua informan menyebutkan bahwa lingkungan dan pergaulan memberikan pengaruhnya terhadap minat berwirausaha. 


\section{Alasan Lingkungan dan Pergaulan dapat Memengaruhi Seseorang untuk Berwirausaha}

Sesuai dengan Motto SMK Plus Pelita Nusantara yaitu success by character (terampil, entrepreneur, dan religius). Jadi sekolah mewajibkan peserta didik berwirausaha kemudian mempraktikannya secara langsung. Untuk pergaulan dan pengalaman dari teman-teman yang berwirausaha secara langsung memberikan dampak yang positif yaitu dapat menimbulkan minat untuk berwirausaha dan memulainya. Peneliti menyimpulkan bahwa lingkungan dan pergaulan pada dasarnya dapat mendorong peserta didik untuk menumbuhkan jiwa wirausaha. Sehingga peserta didik mempunyai semangat, kemampuan, dan pikiran untuk berwirausaha dengan baik.

\section{CONCLUSION}

Berdasarkan pengumpulan, pengolahan, dan penginterpretasian data, maka peneliti menyimpulkan bahwa minat atau rasa ketertarikan peserta didik terhadap berwirausaha masih perlu ditingkatkan dan dilatih lagi. Hal itu disebabkan oleh peserta diidk yang merasa kurang memiliki rasa percaya diri, kurang kreatif, kurangnya modal serta tidak mau mengambil resiko kerugian dari sebuah usaha. Namun keadaan tersebut dapat ditingkatkan dengan peran media sosial instagram yang mereka miliki. Apabila peserta didik memiliki akun instagram yang memiliki banyak followers maka kemungkinan besar produk yang dijual akan semakin banyak yang membeli. Sehingga peneliti dapat memastikan bahwa peran media sosial instagram dapat meningkatkan minat berwirausaha peserta didik.

\section{REFERENCES}

Adinda, S dan Pangestuti, E. (2019). Pengaruh Media Sosial Instagram @explormalang Terhadap Minat Berkunjung Followers Ke Suatu Destinasi (Survey Pada Followers @ exploremalang). Jurnal Administrasi Bisnis. Volume 72 Nomor 1 Juli 2019.

Aditya, R. (2015). Pengaruh Media Sosial Instagram Terhadap Fotografi Pada Komunitas Fotografi Pekanbaru.Jurnal Online mahasiswa Fakultas Ilmu Sosial dan Ilmu Politik Universitas Riau. Volume 2 Nomor 2 Tanggal 2 Oktober 2015.

Anwar, M. (2014). Pengantar Kewirausahaan Teori dan Aplikasi. Jakarta: Kencana.

Databoks.(2020). 10 Media Sosial yang Paling Sering Digunakan di Indonesia. Https://databoks.katadata.co.id/datapublish/2020/02/26/10. Diakses pada 11 Juni 2020.

Fikrian, M. (2018). Analisis Peran Media Sosial Instagram Terhadap Minat Berwirausaha Mahasiswa dalam Perspektif Ekonomi Islam. Skripsi. Universitas Islam Negeri Raden Intan Lampung.

Kashmir. (2011). Kewirausahaan. Jakarta: Rajawali Pers.

Nordiana, E. (2014). Peran Jejaring Sosial Sebagai Media Peningkat Minat Berwirausaha Untuk Berbisnis Online (Studi Pada Mahasiswa Jurusan Ilmu Ekonomi Universitas Brawijaya). Jurnal Ilmiah Mahasiswa FEB. Volume 2 Nomor 2 tahun 2014.

Nurkarima, N.(2018). Pengaruh Penggunaan Media Sosial Terhadap Akhlakul karimah dan Akhlakul Madzmumah Siswa di SMAN 1 Kauman Tahun Ajaran 2017/2018. Skripsi. Institut Agama Islam Negeri Tulungagung. 
Cania, N. \& Heryani, R. D. / Reseacrh and Development Journal of Education, (Special Edition), 91101

Rahayu, E.S. dan Laela, S. (2018). Pengaruh Minat Berwirausaha dan Penggunaan Sosial Media Terhadap Kewirausahaan Mahasiswa. Jurnal Pengembangan Wiraswasta. Volume 20 Nomor 03 Desember 2018.

Sidiq, A. (2017). Pemanfaatan Instagram Sebagai Media Dakwah (Study Akun @ Fuadbakh). Skripsi. Universitas Negeri Raden Intan Lampung.

Suryana, Y dan Bayu, K. (2010). Kewirausahaan Pendekatan Karakteristik Wirausahawan Sukses. Jakarta: Kencana.

Wulandari, S. (2013). Pengaruh Efikasi Diri Terhadap Minat Berwirausaha Pada Siswa Kelas XII di SMK Negeri 1 Surabaya. Jurnal Pendidikan Tata Niaga. Volume 1 Nomor 1. 